\title{
A LARGE MORGANUCODONTAN MAMMALIAFORM FROM THE LATE JURASSIC OF GERMANY
}

\author{
THOMAS MARTIN ${ }^{1, *}$, ALEXANDER O. AVERIANOV ${ }^{1,2,3}$, KAI R. K. JÄGER $^{1}$, ACHIM H. SCHWERMANN ${ }^{4}$, OLIVER \\ WINGS
}

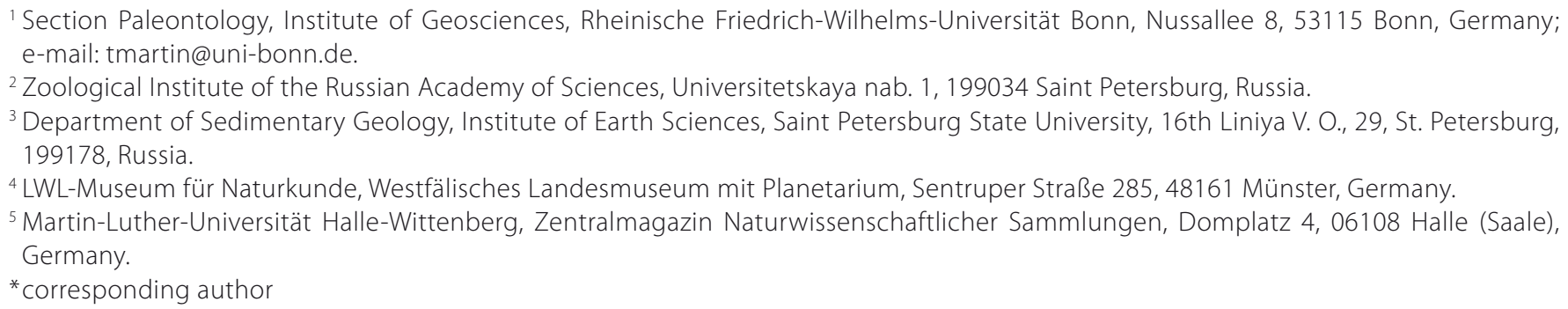

Martin, T., Averianov, A. O., Jäger, K. R. K., Schwermann, A. H., Wings, O. (2019): A large morganucodontan mammaliaform from the Late Jurassic of Germany. - Fossil Imprint, 75(3-4): 504-509, Praha. ISSN 2533-4050 (print), ISSN 2533-4069 (online).

\begin{abstract}
An upper "triconodont" molar from the Late Jurassic (late Kimmeridgian) of the Langenberg Quarry in northern Germany is attributed to Storchodon cingulatus gen. et sp. nov. of Morganucodonta. The molar is characterized by continuous lingual and buccal cingula, and a relatively large, buccally-shifted cusp D which is not integrated in the buccal cingulum. With a length of $3.07 \mathrm{~mm}$, the tooth is less than $10 \%$ smaller than the lower holotype molar of Paceyodon davidi, the largest known morganucodontan. The Langenberg morganucodontan possibly represents an example of insular gigantism on an adjacent paleoisland.
\end{abstract}

Key words: Kimmeridgian, Jurassic, Langenberg Quarry, Morganucodonta, Storchodon cingulatus, Süntel Formation

Received: February 28, 2019 | Accepted: October 7, 2019 | Issued: December 30, 2019

\section{Introduction}

Surprisingly, the marine carbonates of the Langenberg Quarry in Lower Saxony, Germany (Text-fig. 1), have yielded a diverse assemblage of not only marine but also terrestrial Late Jurassic vertebrates (Wings and Sander 2012, Wings 2015). The terrestrial components of the assemblage comprise lizards, atoposaurid crocodyliforms, pterosaurs, the dwarf sauropod dinosaur Europasaurus, several taxa of theropod dinosaurs, and multituberculate mammals (Fastnacht 2005, Karl et al. 2006, Sander et al. 2006, Richter et al. 2013, Carballido and Sander 2014, Lallensack et al. 2015, Marpmann et al. 2015, Gerke and Wings 2016, Martin et al. 2016, 2019, Schwarz et al. 2017). Multituberculates are the most abundant mammals from the Langenberg quarry, represented by several paulchoffatiid and pinheirodontid teeth. Other mammals include a docodontan, a dryolestidan, and the new stem mammal described herein.

The microvertebrate remains from the Langenberg Quarry were recovered by screen-washing of fossiliferous matrix from the Süntel Formation. This stratigraphic unit includes mostly marine strata and is well dated as late Kimmeridgian (Late Jurassic) by marine invertebrates (Lotze 1968, Pape 1970, Fischer 1991, Zuo et al. 2017). The formation was accumulated in a nearshore basin with influx of terrestrial clastics containing also the remains of terrestrial vertebrates.

The tooth was scanned with a resolution of $3.25 \mu \mathrm{m}$ using the $180 \mathrm{kV}$ x-ray tube of the v|tome|x s $\mu \mathrm{CT}$ device (GE Sensing \& Inspection Technologies GmbH phoenix|xray) housed in the Institute of Geosciences, University of Bonn, Germany. Scan settings were $120 \mathrm{kV}$ and $110 \mu \mathrm{A}$ and a shutter speed of $400 \mathrm{~ms}$ per capture. The instrument produces isotropic voxels, and single image size is $1024 \times$ 1024 pixels. Avizo 8 (Thermo Fisher Scientific) was used for segmentation. The Langenberg specimen is curated at the Niedersächsisches Landesmuseum, Hannover, Germany (NLMH). A cast of a right upper molar of Morganucodon watsoni, UMZC_Eo.M(Ur).27 from the University Museum of Zoology Cambridge (UMZC) was scanned for comparison. The cast was scanned with a resolution of $8.98 \mu \mathrm{m}$ using the $180 \mathrm{kV}$ x-ray tube of the v|tome $\mid \mathrm{x} \mathrm{s} \mu \mathrm{CT}$ 
device in Bonn. Scan settings were $112 \mathrm{kV}$ and $112 \mu \mathrm{A}$ and a shutter speed of $500 \mathrm{~ms}$ per capture.

In systematics of Mesozoic mammals and dental terminology, we follow Kielan-Jaworowska et al. (2004) and Martin (2018).

\section{Systematic palaeontology}

\section{Class Mammalia Linnaeus, 1758 \\ Stem group to crown Mammalia \\ Order Morganucodonta KerMack, \\ Musset et Rigney, 1973}

\section{Genus Storchodon gen. nov.}

Ty p e species. Storchodon cingulatus sp. nov.

Etymology. The genus is named after the German palaeomammalogist Gerhard Storch (1939-2017) and Ancient Greek ỏoov́s (tooth).

Differential diagnosis. The new taxon is referred to the Morganucodonta because of the longitudinally aligned main cusps, the small height difference between the central cusp A and the side cusps B and C, and the presence of a well-defined lingual cingulum. In crown mammals with longitudinally aligned main cusps on the molars (Eutriconodonta) the central cusp is significantly larger than the side cusps (Amphilestidae, Gobiconodontidae), or the main cusps are of equal height but labiolingually compressed and sectorial (Triconodontidae). Furthermore, in Storchodon gen. nov. and Morganucodonta in general the lingual cingulum is cuspate and generally stronger than in Eutriconodonta. Differs from Morganucodon KüHNE, 1949 by more erect main cusps, large size of cusp C, a less reduced cusp B, cusp $\mathrm{D}$ not being cingular, the lack of an upper molar interlock between cusps D and E-F, and by being considerably larger than Morganucodon watsoni (size difference to M. oehleri less pronounced). Differs from Helvetiodon Clemens, 1980, Bridetherium Clemens, 2011 and Paceyodon Clemens, 2011 by proportionally larger side cusps. Differs from Indotherium YADAGIRI, 1984 by an unreduced cusp B and a cuspidate cingulum. Differs from Indozostrodon DatTA et DAS, 2001 by an unreduced cusp $\mathrm{C}$, a cuspidate cingulum and a continuous buccal cingulum. Differs from Megazostrodon CROMPTON et JENKINS, 1968 by larger side cusps and a complete buccal cingulum with smaller cuspules. Differs from Brachyzostrodon Sigogneau-Russell, 1983 and Wareolestes Freeman, 1979 by larger side cusps and lack of enamel sculpture. Differs from Dinnetherium Jenkins, Crompton et Downs, 1983 by much larger side cusps and continuous buccal and lingual cingula. By the relative height of the erect cusps, the new taxon is most similar to Erythrotherium CROMPTON, 1964. Differs from Erythrotherium by non-coalesced cusps A and C, cusp D not being cingular, a higher number of cingular cusps, a labiolingually wider crown, and the lack of an upper molar interlock between cusps D and E-F.

\section{Storchodon cingulatus sp. nov.}

Text-figs 2,3

H o l o t y p e. NLMH 105654, a right upper molar.

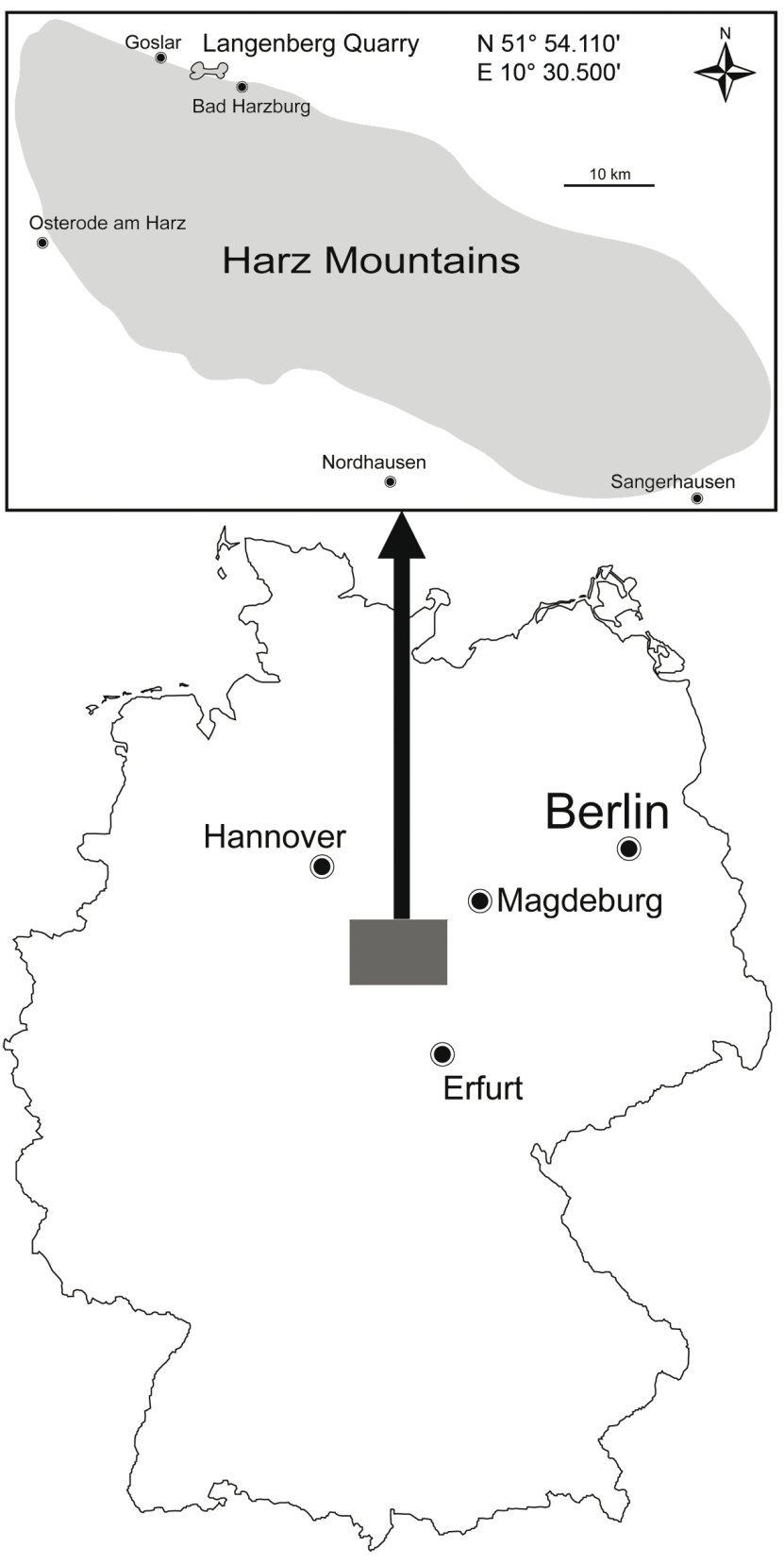

Text-fig. 1. Location of the Langenberg Quarry in northern Germany. Map modified from Martin et al. (2016).

Etymology. The species name refers to the welldeveloped cingulum around the crown.

Referred specimens. Holotype only.

Type locality and horizon. Langenberg Quarry near the town of Goslar, Lower Saxony, northern Germany ( $51^{\circ} 54.110^{\prime}$, E $10^{\circ} 30.500^{\prime}$ ). Bed 83 (after Fischer 1991). The sample was collected in a temporarily exposed dark grey lens of marl within the normally light grey-greenish marly limestone bed. It belongs to the Süntel Formation, Late Jurassic (late Kimmeridgian) age.

Differential diagnosis. As for the genus.

Description. The presence of a continuous cingulum around the crown identifies the tooth as an upper molar (Text-fig. 2); in lower molars of Morganucodonta the buccal cingulid is absent (Kielan-Jaworowska et al. 2004). 

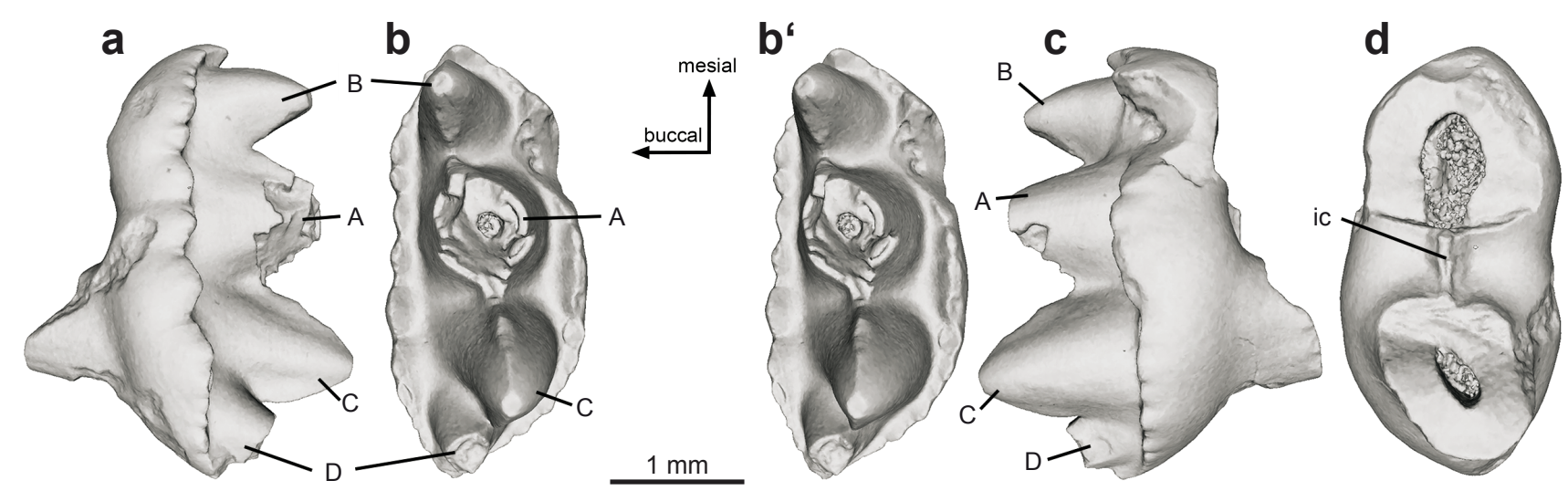

Text-fig. 2. Storchodon cingulatus gen. et sp. nov., NLMH 105654, holotype, right upper molar, in buccal (a), occlusal (b, b' stereopair), lingual (c), and basal (d) views. Langenberg Quarry, Lower Saxony, Germany; Süntel Formation, Late Jurassic (late Kimmeridgian) age. Abbreviations: A, B, C and D, main cusps of the crown; ic, interradical crest.

The three main cusps A, B, and C are aligned serially. Cusp $\mathrm{D}$ is set off this line and sits more lingually compared to cusp C. Thus, the line A-B-C-D is slightly convexly curved in a lingual direction. Cusp A is not completely preserved; its base is only slightly larger than that of cusp C. Cusp A was probably only little higher than cusp C and vertically directed, whereas cusp C is slightly distally oriented. Cusp B has about two thirds the size of cusp C and is slightly mesially directed. The main cusps are connected by a sharp crest which extends to their apices (incompletely preserved on cusp A). This crest is extended on the mesial side of cusp $\mathrm{B}$, as well as on the distal side of cusp $\mathrm{C}$ and on both sides of cusp $\mathrm{D}$. The crown is surrounded by a continuous cingulum bearing numerous cusps. There is a distinct valley between the cingulum and the bases of the main cusps on the buccal, lingual, and mesial sides of the crown. Cusp D (incomplete) is more distally directed than cusp C. Cusp D is not part of the cingulum (a unique character of the new taxon within

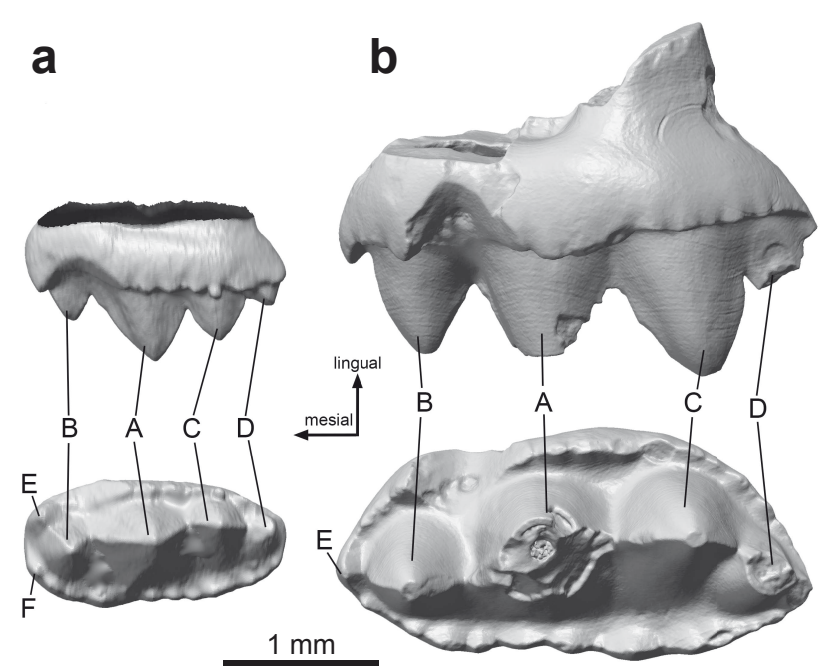

Text-fig. 3. Right upper molars of Morganucodon watsoni KüHNE, 1949, UMZC_Eo.M(Ur).27 (cast) (a) and Storchodon cingulatus gen. et sp. nov., NLMH 105654, holotype (b) in lingual and occlusal views. Abbreviations: A, B, C, D, E and F, main cusps of the crown. Specimens to scale.
Morganucodonta), but is connected distally with a rather large cingular cusp. Only in Erythrotherium and in some individuals of Morganucodon is cusp D equally prominent (Text-fig. 3). A relatively large cingular cusp is situated on the mesial end of the crown; it is separated by a groove from cusp B. This mesial cingular cusp possibly corresponds to cusp E of other morganucodontans. Two large cingular cusps are located on the buccal cingulum opposite to cusp C. Distally and mesially to these cusps, the size of the cingular cusps decreases. Altogether there are 13 cusps on the buccal cingulum and at least 14 cusps on the preserved lingual portion of the cingulum (part of the lingual cingulum between cusps $\mathrm{B}$ and $\mathrm{A}$ is missing due to dental wear). The size variation between the lingual cingular cusps is smaller than that of the buccal cingular cusps. The lingual cingulum is elevated opposite to cusp A and between cusps A and C, similar to the "protocone" in the "symmetrodontan" mammal Yermackia from the Early Cretaceous of West Siberia (Averianov and Lopatin 2008). The mesial and distal sides of the crown are rhomboidal with pointed ends. This, and the lack of mesial cingular cusps $\mathrm{E}$ and $\mathrm{F}$ with an embayment between them, indicates that the new taxon lacked an upper molar interlock between cusps D and E-F, which is also seen in Indotherium, Indozostrodon and Bridetherium (Prasad and Manhas 1997, Datta and Das 2001, Clemens 2011). The molar contact in the maxilla was likely imbricating. The tips of cusps B and $\mathrm{C}$ have small apical abrasion facets, but otherwise the cusps are unworn. There is a large wear facet on the lingual side between cusps A and B which was caused by cusp a of the lower antagonist, and a small facet between cusps A and C (caused by cusp c of the antagonist). According to Mills (1971), the cingulum wears rapidly on the lingual side in Morganucodon. The insignificant apical wear and the only partially worn lingual cingulum suggest that NLMH 105654 was only recently erupted. This occlusal mode is identical with the one described for Morganucodon (Crompton and Jenkins 1968). There are two roots connected basally by an interradical crest (Text-fig. 2d). The mesial root has a normal position while the distal root is set obliquely to the longitudinal axis of the crown. This apparently reflects an oblique position of cusp D relative to cusp C (both cusps are supported by the distal root). The pulp cavity of the 
distal root is smaller compared with that of the mesial root. The distal root is oval in cross section, with the mesiodistal diameter being larger than the buccolingual one.

M e a s u re m e n t s. Length $3.07 \mathrm{~mm}$, width $1.44 \mathrm{~mm}$.

\section{Discussion}

In spite of the linear alignment of the main cusps in NLMH 105654, the crown shows a slight cusp angulation because cusp D is set off the line formed by cusps A, B, and $\mathrm{C}$ (Text-fig. 2b). A similar angulation is present in Erythrotherium, but there cusp B is set off the line formed by cusps A, C, and D (Crompton 1974: pl. 1, fig. B). In Megazostrodon the upper molar main cusps are smaller relative to the tooth size and less centered (offset towards lingual), due to a smaller lingual cingulum and large buccal cingular cusps (Crompton 1974: fig. 6B).

The Kimmeridgian Storchodon gen. nov. is the youngest unambiguous representative of the Morganucodonta in the fossil record. Purbeckodon Butler, Sigogneau-Russell et ENSOM, 2012 from the Lower Cretaceous Purbeck Limestone Group (Dorset, England) has tentatively been attributed to Morganucodonta indet. (Butler et al. 2012). The previously youngest unambiguous records of this group were from the Middle Jurassic (Bathonian) of England: Wareolestes rex Freeman, 1979 (also from Scotland), Morganucodon tardus Butler et Sigogneau-Russell, 2016, Cherwellia leei Butler et Sigogneau-Russell, 2016 and Stylidens hookeri Butler et Sigogneau-Russell, 2016 (Freeman 1979, Butler and Sigogneau-Russel 2016, Panciroli et al. 2017), as well as Morganucodonta indet., based on a femur from the Middle Jurassic (Bathonian) of Moscow Province, Russia (Gambaryan and Averianov 2001). This new record extends the known stratigraphic range of the Morganucodonta by appoximately $20 \mathrm{Ma}$. Storchodon gen. nov. was a member of an insular fauna inhabiting a paleoisland within the Late Jurassic Lower Saxony Basin. This fauna apparently developed in isolation for a sufficient time for insular evolutionary phenomena such as insular dwarfism and possibly also insular gigantism to be developed (i.e. large animals become smaller and small animals become larger, respectively) (Sander et al. 2006). The island fauna included the dwarf sauropod dinosaur Europasaurus and the large multituberculate mammal Teutonodon. Storchodon gen. nov. was also a quite large Mesozoic mammal, one of the largest representatives of Morganucodonta known so far, second only to Paceyodon davidi (lower molar length: $3.3 \mathrm{~mm}$ ) and similar to Brachyzostrodon major (lower molar length: $2.7 \mathrm{~mm}$ ) (Hahn et al. 1991, Clemens 2011). In the insular ecosystem Storchodon gen. nov. likely played a role as a second or even third order consumer, preying potentially on smaller mammals, other small vertebrates, and possibly hard-shelled arthropods, the latter also suggested for Morganucodon (Gill et al. 2014). The sharp crests connecting the main cusps on the molar support a faunivorous habit. The isolation of the Langenberg Biota, obviously documented by the striking dwarfism in Europasaurus and probable gigantism of mammals, likely facilitated the survival of relict taxa, such as Storchodon gen. nov. (if the morganucodontan nature of Purbeckodon from the Early Cretaceous southern England is disproven).

\section{Acknowledgements}

Nils Knötschke (Dinosaurier-Park Münchehagen), preparators, student helpers and volunteers are acknowledged for help during fieldwork. Jens Lallensack sorted the sedimentary matrix and Thomas Engler (both University of Bonn) scanned the specimen. The late Fabian von Pupka (Rohstoffbetriebe Oker) provided access to the Langenberg Quarry and logistic assistance. Robert Asher (University Museum of Zoology, Cambridge, UK) granted access to comparative material of Morganucodon. We thank the reviewers Rich Cifelli (Norman) and Pam Gill (Bristol) for their constructive comments. AA was supported by the Zoological Institute, Russian Academy of Sciences (project AAAA-A17-117022810195-3) and a Humboldt Research Award by the Alexander von Humboldt Foundation. The Europasaurus-Project (grant no. 85 882) and OW were generously funded by the Volkswagen Foundation within the initiative "Research in Museums". This study was also supported by grant MA $1643 / 20-1$ of the Deutsche Forschungsgemeinschaft (DFG; German Research Foundation) to TM.

\section{References}

Averianov, A. O., Lopatin, A. V. (2008): "Protocone" in a pretribosphenic mammal and upper dentition of tinodontid "symmetrodontans". - Journal of Vertebrate Paleontology, 28: 548-552.

https://doi.org/10.1671/0272-4634(2008)28[548:PIAPMA]2.0.CO;2

Butler, P. M., Sigogneau-Russell, D. (2016): Diversity of triconodonts in the Middle Jurassic of Great Britain. Palaeontologia Polonica, 67: 35-65. http://dx.doi.org/10.4202/pp.2016.67_035

Butler, P. M., Sigogneau-Russell, D., Enson, P. C. (2012): Possible persistence of the morganucodontans in the Lower Cretaceous Purbeck Limestone Group (Dorset, England). - Cretaceous Research, 33: 135-145. https://doi.org/10.1016/j.cretres.2011.09.007

Carballido, J. L., Sander, P. M. (2014): Postcranial axial skeleton of Europasaurus holgeri (Dinosauria, Sauropoda) from the Upper Jurassic of Germany: implications for sauropod ontogeny and phylogenetic relationships of basal Macronaria. - Journal of Systematic Palaeontology, 12: 335-387.

https://doi.org/10.1080/14772019.2013.764935

Clemens, W. A. (1980): Rhaeto-Liassic mammals from Switzerland and West Germany. - Zitteliana, 5: 51-92.

Clemens, W. A. (2011): New morganucodontans from an Early Jurassic fissure filling in Wales (United Kingdom). - Palaeontology, 54: 1139-1156. https://doi.org/10.1111/j.1475-4983.2011.01094.x

Crompton, A. W. (1964): A preliminary description of a new mammal from the Upper Triassic of South Africa. - Proceedings of the Zoological Society of London, 142: $441-452$. https://doi.org/10.1111/j.1469-7998.1964.tb04508.x

Crompton, A. W. (1974): The dentitions and relationships of the southern African Triassic mammals Erythrotherium 
parringtoni and Megazostrodon rudnerae. - Bulletin of the British Museum (Natural History), Geology, 24: 397-437.

Crompton, A. W., Jenkins, F. A., Jr. (1968): Molar occlusion in Late Triassic mammals. - Biological Reviews, 43: $427-458$.

https://doi.org/10.1111/j.1469-185X.1968.tb00966.x

Datta, P. M., Das, D. P. (2001): Indozostrodon simpsoni, gen. et sp. nov., an Early Jurassic megazostrodontid mammal from India. - Journal of Vertebrate Paleontology, 21: 528-534. https://doi.org/10.1671/0272-4634(2001)021[0528:ISGESN]2.0.CO;2

Fastnacht, M. (2005): The first dsungaripterid pterosaur from the Kimmeridgian of Germany and the biomechanics of pterosaur long bones. - Acta Palaeontologica Polonica, 50: 273-288.

Fischer, R. (1991): Die Oberjura-Schichtenfolge des Langenbergs bei Oker. - Arbeitskreis Paläontologie Hannover, 19: 21-36.

Freeman, E. F. (1979): A Middle Jurassic mammal bed from Oxfordshire. - Palaeontology, 22: 135-166.

Gambaryan, P. P., Averianov, A. O. (2001): Femur of a morganucodontid mammal from the Middle Jurassic of Central Russia. - Acta Palaeontologica Polonica, 46: 99-112.

Gerke, O., Wings, O. (2016): Multivariate and cladistic analyses of isolated teeth reveal sympatry of theropod dinosaurs in the Late Jurassic of Northern Germany. - PLoS ONE, 11(7): e0158334 (52 pp.). https://doi.org/10.1371/journal.pone.0158334

Gill, P. G., Purnell, M. A., Crumpton, N., Brown, K. R., Gostling, N. J., Stampanoni, M., Rayfield, E. J. (2014): Dietary specializations and diversity in feeding ecology of the earliest stem mammals. - Nature, 512: 303-305. https://doi.org/10.1038/nature13622

Hahn, G., Sigogneau-Russell, D., Godefroit, P. (1991): New data on Brachyzostrodon (Mammalia; Upper Triassic). Geologica et Palaeontologica, 25: 237-249.

Jenkins, F. A., Jr., Crompton, A. W., Downs, W. R. (1983): Mesozoic mammals from Arizona: new evidence on mammalian evolution. - Science, 222: 1233-1235. https://doi.org/10.1126/science.222.4629.1233

Karl, H.-V., Gröning, E., Brauckmann, C., Schwarz, D., Knötschke, N. (2006): The Late Jurassic crocodiles of the Langenberg near Oker, Lower Saxony (Germany), and description of related materials (with remarks on the history of quarrying the "Langenberg Limestone" and "Obernkirchen Sandstone"). - Clausthaler Geowissenschaften, 5: 59-77.

Kermack, K. A., Mussett, F., Rigney, H. W. (1973): The lower jaw of Morganucodon. - Zoological Journal of the Linnean Society, 53: 87-175. https://doi.org/10.1111/j.1096-3642.1973.tb00786.x

Kielan-Jaworowska, Z., Cifelli, R. L., Luo, Z.-X. (2004): Mammals from the Age of Dinosaurs: Origins, Evolution, and Structure. Columbia University Press, New York, $630 \mathrm{pp}$. https://doi.org/10.7312/kiel11918

Kühne, W. G. (1949): On a triconodont tooth of a new pattern from a fissure-filling in South Glamorgan. - Proceedings of the Zoological Society of London, 119: 345-350. https://doi.org/10.1111/j.1096-3642.1949.tb00883.x
Lallensack, J. N., Sander, P. M., Knötschke, N., Wings, O. (2015): Dinosaur tracks from the Langenberg Quarry (Late Jurassic, Germany) reconstructed with historical photogrammetry: Evidence for large theropods soon after insular dwarfism. - Palaeontologia Electronica, 18.2.31A: 1-34. https://doi.org/10.26879/529

Linnaeus, C. (1758): Systema naturae per regna tria naturae, secundum classes, ordines, genera, species, cum characteribus, differentiis, synonymis, locis. Vol. 1: Regnum animale. Editio decima, reformata. - Laurentius Salvius, Holmiae [Stockholm], 824 pp. https://doi.org/10.5962/bhl.title.542

Lotze, F. (1968): Zum Jura des Langenberges zwischen Oker und Bad Harzburg (nördl. Harzrand). - Neues Jahrbuch für Geologie und Paläontologie, Monatshefte, 1968: 730-732.

Marpmann, J. S., Carballido, J .L., Sander, P. M., Knötschke, N. (2015): Cranial anatomy of the Late Jurassic dwarf sauropod Europasaurus holgeri (Dinosauria, Camarasauromorpha): ontogenetic changes and size dimorphism. - Journal of Systematic Palaeontology, 13: 221-263.

https://doi.org/10.1080/14772019.2013.875074

Martin, T. (2018): Mesozoic mammals - early mammalian diversity and ecomorphological adaptations. - In: Zachos, F. E., Asher, R. J. (eds), Handbook of Zoology, Mammalia. Mammalian Evolution, Diversity and Systematics. De Gruyter, Berlin, pp. 199-299. https://doi.org/10.1515/9783110341553-006

Martin, T., Averianov, A. O., Schultz, J. A., Schwermann, A. H., Wings, O. (2019): Late Jurassic multituberculate mammals from Langenberg Quarry (Lower Saxony, Germany) and palaeobiogeography of European Jurassic multituberculates. - Historical Biology, [published online]. https://doi.org/10.1080/08912963.2019.1650274

Martin, T., Schultz, J. A., Schwermann, A. H., Wings, O. (2016): First Jurassic mammals of Germany: Multituberculate teeth from Langenberg Quarry (Lower Saxony). - Palaeontologia Polonica, 67: 171-179. http://dx.doi.org/10.4202/pp.2016.67_171

Mills, J. R. E. (1971): The dentition of Morganucodon. - In: Kermack, D. M., Kermack, K. A. (eds), Early Mammals. Zoological Journal of the Linnean Society, London, 50(Supplement 1): 29-63.

Panciroli, E., Benson, R. B. J., Walsh, S. A. (2017): The dentary of Wareolestes rex (Megazostrodontidae): a new specimen from Scotland and implications for morganucodontan tooth replacement. - Papers in Palaeontology, 3: 373-386. https://doi.org/10.1002/spp2.1079

Pape, H. (1970): Die Malmschichtfolge vom Langenberg bei Oker (nördl. Harzvorland). - Mitteilungen aus dem Geologischen Institut der Technischen Universität Hannover, 9: 41-134.

Prasad, G. V. R., Manhas, B. K. (1997): A new symmetrodont mammal from the Lower Jurassic Kota Formation, Pranhita-Godavari Valley, India. - Geobios, 30: 563-572. https://doi.org/10.1016/S0016-6995(97)80122-2

Richter, A., Knötschke, N., Kosma, R., Sobral, G., Wings, O. (2013): The first Mesozoic lizard from northern Germany (Paramacellodidae, Late Jurassic, Langenberg 
Quarry) and its taphonomy. - In: Program and Abstracts, Society of Vertebrate Paleontology $73^{\text {rd }}$ Annual Meeting, October 30-November 2, 2013, Los Angeles, USA. Supplement to the online Journal of Vertebrate Paleontology, October 2013: 198.

Sander, P. M., Mateus, O., Laven, T., Knötschke, N. (2006): Bone histology indicates insular dwarfism in a new Late Jurassic sauropod dinosaur. - Nature, 441: 739-741. https://doi.org/10.1038/nature04633

Schwarz, D., Raddatz, M., Wings, O. (2017): Knoetschkesuchus langenbergensis gen. nov. sp. nov., a new atoposaurid crocodyliform from the Upper Jurassic Langenberg Quarry (Lower Saxony, northwestern Germany), and its relationships to Theriosuchus. - PLoS ONE, 12(2): e0160617 (47 pp.).

https://doi.org/10.1371/journal.pone.0160617

Sigogneau-Russell, D. (1983): Nouveaux taxons de Mammifères rhétiens. - Acta Palaeontologica Polonica, 28: 233249.
Wings, O. (2015): The Langenberg Quarry near Goslar: Unique window into a terrestrial Late Jurassic ecosystem in Northern Germany. - In: Zhang, Y, Wu, S. Z., and Sun, G. (eds) Abstracts, $12^{\text {th }}$ Symposium of Mesozoic Terrestrial Ecosystems, August 16th-20th 2015, Shenyang, China, pp. 99-100.

Wings, O., Sander, P. M. (2012): The Late Jurassic vertebrate assemblage of the Langenberg Quarry, Oker, Northern Germany. - ¡Fundamental!, 20: 281-284.

Yadagiri, P. (1984): New symmetrodonts from the Kota Formation (Early Jurassic), India. - Journal of the Geological Society of India, 25: 514-521.

Zuo, F., Heimhofer, U., Huck, S., Luppold, F. W., Wings, O., Erbacher, J. (2017): Sedimentology and depositional sequences of a Kimmeridgian carbonate ramp system, Lower Saxony Basin, Northern Germany. - Facies, 64: 1 (25 pp.).

https://doi.org/10.1007/s10347-017-0513-0 